НАУКОВИЙ ВІСНИК

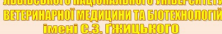

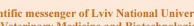
(1) TERIES: FOOD TECHNOLOCIS 23 № 95 2021

\section{Науковий вісник Львівського національного університету} ветеринарної медицини та біотехнологій імені С.3. Гжицького. Серія: Харчові технології

\author{
Scientific Messenger of Lviv National University \\ of Veterinary Medicine and Biotechnologies.
}

Series: Food Technologies

ISSN 2519-268X print

doi: 10.32718/nvlvet-f9509

ISSN 2707-5885 online https://nvlvet.com.ua/index.php/food

UDC 663.674:664.162.8:616.379-008.64

\title{
Development of ice cream recipe with dates processing products
}

\author{
O. Ya. Bilyk, N. B. Slyvka, V. O. Nagovska, O. R. Mykhaylytska \\ Stepan Gzhytskyi National University of Veterinary Medicine and Biotechnologies Lviv, Ukraine
}

Article info

Received 18.01.2021

Received in revised form 22.02.2021

Accepted 23.02.2021

Stepan Gzhytskyi National University of Veterinary Medicine and Biotechnologies Lviv, Pekarska Str., 50, Lviv, 79010, Ukraine.

Tel.: + 38-067-275-37-25

E-mail:slyvkanat@ukr.net
Bilyk, O. Ya., Slyvka, N. B., Nagovska, V. O., \& Mykhaylytska, O. R. (2021). Development of ice cream recipe with dates processing products. Scientific Messenger of Lviv National University of Veterinary Medicine and Biotechnologies. Series: Food Technologies, 23(95), 51-56. doi: $10.32718 /$ nvlvet-f9509

The trend of healthy eating determines several areas of modern consumer trends: the Ukrainian buyer pays more attention to the naturalness of ice cream and more carefully analyzes the ingredient composition of the product. More popular is ice cream, which does not contain synthetic dyes and flavors and is lower in sucrose. The article substantiates the use of dates processing products in ice cream technology. The aim of the work was to develop ice cream technology with partial and complete replacement of sucrose with date paste and date syrup. The research was conducted at the Department of Milk and Dairy Products Technology at Stepan Gzhytskyi National University of Veterinary Medicine and Biotechnologies Lviv. The raw materials used for research met the requirements of current regulations in terms of quality and safety. Date paste was made independently, hazelnut oil was added to it. Organic date syrup was used under the trademark Bio Planet. Four ice cream recipes were developed and technological operations of ice cream production with dates processed products were worked out. Denise 855 was used as a stabilizer and emulsifier in the ice cream recipe, which gives an unsurpassed creamy taste and homogeneous structure and provides the initial air distribution and stable whipping. In the study of organoleptic characteristics of ice cream, it was found that all samples had a similar sense of aroma and taste - with the taste of dates. The addition of date syrup improved the taste of ice cream. Taste indices increased significantly with increasing concentration of date syrup. Complete replacement of granulated sugar with date syrup significantly lowered the $\mathrm{pH}$ and increased acidity. In addition, the replacement of sucrose with date processed products has been shown to increase the viscosity of ice cream. The lowest viscosity value was observed in the control sample, while the highest viscosity value was obtained when the sugar was completely replaced with date syrup.

Key words: ice cream, dates, syrup, technology, recipe.

\section{Розробка рецептури морозива 3 продуктами переробки фініків}

\author{
О. Я. Білик, Н. Б. Сливка, В. О. Наговська, О. Р. Михайлицька
}

Львівський національний університет ветеринарної медицини та біотехнологій імені С. 3. Гжсицького, м. Львів, Україна

Тенденція до здорового харчування визначає кілька напрямків сучасних споживчих трендів: украӥнський покупець більше зважає на натуральність морозива і ретельніме аналізує інгредієнтний склад продукту. Популярнішим є морозиво, в якому відсутні синтетичні барвники і ароматизатори та мениий вміст сахарози. У статті обтрунтовано використання продуктів переробки фініків у технології морозива. Метою роботи було розробити технологію морозива з частковою та повною заміною сахарози на фінікову пасту $i$ фініковий сироп. Дослідження проводили на кафедрі технології молока і молочних продуктів ЛНУВМБ імені С. 3. Гжицького. Сировина, щуо використовувалась для досліджень, відповідала за якістю і безпечністю вимогам діючої нормативної документації. Фінікову пасту виготовляли самостійно, до неї додавали олію фундука. Сироп фініковий органічний використовували торгової марки Віо Plaпеt. Було розроблено чотири рецептури морозива та відпрацьовано технологічні операції виробниитва морозива із продуктами переробки фініків. Як стабілізатор і емульгатор у рецептурі морозива використовували Денайс 855, який надає неперевершеного вершкового смаку й однорідної структури та забезпечує вихідне розподілення повітря та стабільну збитість. При дослідженні органолептичних показників морозива встановлено, щцо всі зразки мали подібне відчуття аромату $і$ смаку - зі смаком фініків. Додавання фінікового сиропу поліпшувало смак морозива. Показники смакових відчуттів суттєво зрос- 
тали зі збільшенням концентрації фінікового сиропу. Повна заміна иукру-піску на фініковий сироп значно знизила рН та підвищила кислотність. Крім того, досліджено, щзо заміна сахарози на продукти переробки фініків збільшила в'язкість морозива. Найнижче значення в'язкості спостерігалось у контрольній пробі, тимчасом як при повній заміні иукру фініковим сиропом було отримано найвище значення в 'язкості.

Ключові слова: морозиво, фініки, сироп, технологія, рецептура.

\section{Вступ}

Ринок морозива є одним з розвинених сегментів харчової промисловості України. Морозиво - це заморожений продукт, який вживають у всьому світі. Це багатофазна харчова система, яка включає кристали льоду, бульбашки повітря, білково-гідроколоїдні структури, кріоконцентровану водну фазу, емульгований жир, білки та солі. Тому морозиво можна розглядати як емульсію жир-у-воді (Gouhari Ardebili et al., 2005; Bartkovskyi et al., 2010; Zgurskyi et al., 2015).

За останні роки спостерігається зростання виробництва морозива в Україні (Kravchenko, 2017). Вітчизняні виробники займають тверді позиції. Водночас варто зазначити, що головною проблемою на українському ринку морозива $\epsilon$ невисока платоспроможність жителів України. Українці щороку в середньому споживають близько 2 кг морозива, в Свропі цей показник становить 8-10 кг, в Америці - понад 20 кг на рік. Потенційно рівень ринку може збільшитись як мінімум - у 5 разів. 3 іншого боку, на українському ринку помітна тенденція зростання споживання морозива середнього і високого цінових сегментів. Таким чином, український ринок має перспективи на подальший позитивний розвиток (Mostova et al., 2015; Vezhlivtseva \& Riaba, 2019).

Напрями інноваційних технологій у виробництві морозива зумовлені вимогами споживачів. Зараз споживачі шукають нових видів морозива 3 різними ароматизаторами, що не відповідають їх звичній практиці. Також основним фактором, що бажали б споживачі нових заморожених десертів, $\epsilon$ нова текстура, зокрема різноманітний хрусткіт, аерація тощо (Ozdemir et al., 2008; Pavliuk et al., 2013; Sharakhmatova \& Tanasova, 2015).

Також актуальними залишаються пропозиції безмолочного морозива. Ця тенденція не нова, але за останні кілька років набрала значних обертів. Це пов'язано $з$ двома факторами: по-перше, споживачі змінюють свій раціон, оскільки фізично не можуть споживати продукти 3 молочними продуктами. Подруге, вони приймають свідоме або соціальне рішення не вживати продукти тваринного походження.

Включення до рецептур нових інгредієнтів, часто непоєднуваних, із категорії ф'южн - теж забаганка споживачів. Прикладом може бути шоколадне морозиво з солоною карамеллю, із плісеневими сирами і навіть 3 морепродуктами.

Оскільки споживачі надають перевагу здоровому харчуванню, тенденції в цій галузі будуть продовжувати зростати (Turchyn et al., 2013).

Варто зазначити, що при виробництві морозива застосовують велику кількість цукру, оскільки цей компонент впливає на якісні характеристики готового продукту. Тому актуальним $є$ пошук альтернативних замінників сахарози у рецептурах морозива.
Одним з поширених вуглеводовмісних рослинних джерел є фініки. Фініки містять природні цукри, такі як глюкоза, сахароза та фруктоза. Їх можна використовувати як швидкий перекус. Фініки $є$ потужним джерелом білків, які допомагають підтримувати фізичну форму і навіть підтримують міцність м'язів. Вони містять вітаміни $\mathrm{B}_{1}, \mathrm{~B}_{2}, \mathrm{~B}_{3}$ i $\mathrm{B}_{5}$, а також $\mathrm{A}$ і C. Фініки не містять холестерину і містять дуже мало жиру (Milani \& Koocheki, 2011). Включення їх у невеликій кількості до щоденного раціону може допомогти контролювати рівень холестерину і навіть сприятиме зниженню ваги. Фініки багаті селеном, марганцем, міддю і магнієм, і все це потрібно, коли йдеться про підтримку здоров'я наших кісток та профілактику таких станів, як остеопороз. Вони багаті на калій, i при цьому містять мало натрію, i це значно сприяє підтримці нервової системи (Habib \& Ibrahim, 2009; Yang1lar, 2015). Калій допомагає знизити рівень холестерину та контролює ризик інсульту. Окрім фтору, фініки також містять залізо, яке постійно рекомендується тим, хто страждає від нестачі заліза. Важка залізодефіцитна анемія може спричинити втому, задишку або біль у грудях. Крім того, він чудово підходить для очищення крові. Через високий вміст клітковини рекомендується також тим, хто має проблеми зі шлунково-кишковим трактом (Ahmed et al., 1995; Al-Farsi \& Lee, 2008).

Мета роботи - розробити рецептуру морозива 3 частковою або повною заміною сахарози на продукти переробки фініків, а саме фініковою пастою і фініковим сиропом.

\section{Матеріал і методи досліджень}

Дослідження проводили на кафедрі технології молока і молочних продуктів ЛНУВМБ імені С. 3. Гжицького.

Сировина, що використовувалась для досліджень, відповідала за якістю і безпечністю вимогам діючої нормативної документації.

Відбір проб для досліджень здійснювали відповідно до ГОСТ 8764-73, ГОСТ 26185-84.

Фінікову пасту виготовляли самостійно. 3 фініків видаляють кісточки, поміщають в пароварку зі склянкою води на 10-15 хвилин. Розм'якшені плоди блендерують до отримання пюреподібної маси, додають олію фундука.

Олія має легкий і м'який смак. Для неї характерний світло-бурштиновий або практично прозорий колір. Калорійність продукту - близько 630 ккал на 100 г. У продукті міститься значна кількість рослинного білка. Широкий спектр амінокислот, вкрай важливих для організму. В олії небагато насичених жирів, через це вона засвоюється практично повністю. До складу входять ненасичені жирні кислоти - до $93 \%$ від денної норми в 100 продукту. В ній багато олеїно- 
вої кислоти. Також містяться лінолева, ліноленова, стеаринова та інші кислоти. Вітаміни (декілька з групи В, а також C, Е, РР). Безліч мінералів (цинк, магній, натрій, залізо, кобальт тощо). Дуже невелика кількість вуглеводів.

На 1000 г фініків додають 50 г олії фундукової.

Використовували сироп фініковий органічний торгової марки Bio Planet. Це біологічна добавка до їжі, що $є$ джерелом фруктози і глюкози. Особливістю продукту $є$ багатий вміст вітамінів і мінеральних речовин. Це густий червоно-рубіновий сироп із концентрованим фруктовим смаком, оскільки виготовляється виключно $з$ фініків та води.

У табл. 1. наведено хімічний склад основної сировини.

\section{Таблиця 1}

Хімічні властивості молока, фінікової пасти і фінікового сиропу

\begin{tabular}{lcrc}
\hline \multicolumn{1}{c}{ Параметри } & Молоко незбиране & Фінікова паста & Фініковий сироп \\
\hline Жир (\%) & $3,36 \pm 0,63$ & & \\
Білок (\%) & $3,71 \pm 0,38$ & & \\
СЗМЗ $(\%)$ & $10,46 \pm 1,15$ & $32,92 \pm 0,64$ & $34,42 \pm 1,28$ \\
Лактоза (г/100 г) & $5,59 \pm 0,62$ & $30,53 \pm 0,20$ & $31,10 \pm 1,51$ \\
Глюкоза (г/100 г) & & $8,96 \pm 0,98$ & \\
Фруктоза (г/100 г) & & & \\
Сахароза (г/100 г & $0,66 \pm 0,18$ & & \\
Мінерали (\%) & $86,18 \pm 1,78$ & & \\
Вологість (\%) & $-0,59 \pm 0,07$ & & \\
Точка замерзання $\left({ }^{\circ} \mathrm{C}\right)$ & & & \\
\hline
\end{tabular}

Морозиво виготовляли за чотирма рецептурами.

Рецептура 1 - цукор-пісок використовували для контрольної групи у кількості $18 \%$.

Рецептура 2 - цукор-пісок наполовину замінювали на сироп фініковий - 9 \% цукру і 9 \% сиропу.

Рецептура 3 - цукор-пісок повністю замінювали на сироп фініковий - $18 \%$ сиропу.

Рецептура 4 - цукор пісок наполовину замінювали на фінікову пасту - 9 \% цукру-піску і 9 \% пасти.

Як стабілізатор і емульгатор у рецептурі морозива використовували Денайс 855. Його основні переваги: компенсує зниження якості в рецептах низької вартості; надає неперевершеного вершкового смаку й рівної, однорідної структури; забезпечує вихідне розподілення повітря та добру і стабільну збитість; забезпечує високий опір до танення; запобігає усадці і сповільнює утворення кристалів льоду в процесі зберігання; забезпечує дуже суху екструзію; регулює агломерацію жирів, не створює “жирових пробок” при фризеруванні.

Сухі інгредієнти, включаючи знежирене сухе молоко та суху сироватку, цукор-пісок та емульгатор / стабілізатор Денайс 855 додавали до нагрітого до температури $45^{\circ} \mathrm{C}$ молока незбираного і перемішували. Вносили фінікову пасту чи фініковий сироп. Суміші пастеризували при температурі $80{ }^{\circ} \mathrm{C}$ протягом 1 хв і гомогенізували при тиску 12,5 МПа. Потім їі охолоджували до $15^{\circ} \mathrm{C}$ i зберігали протягом 16 год. при температурі $4{ }^{\circ} \mathrm{C}$ для визрівання. Всі суміші морозива перед фризеруванням були присмачені екстрактом ванілі. Суміш фасували вагою по 120 г, упаковували в пластикові контейнери і загартовували в морозильній камері при температурі $-30{ }^{\circ} \mathrm{C}$ з витримкою 48 годин. Зразки морозива зберігали при температурі $-18{ }^{\circ} \mathrm{C}$ до подальшого аналізу. Процес виготовлення був однаковим для всіх рецептур.

Сенсорний аналіз зразків морозива був проведений через 2 тижні зберігання на кафедрі технології молока і молочних продуктів.
Визначення органолептичних показників морозива. Органолептичні дослідження допомагають виявити вади смаку і запаху сировини та напівфабрикатів, а також готового продукту 3 метою своєчасного усунення причин їх появи. Зовнішній вигляд і колір продукту визначають візуально; консистенцію, структуру та смак морозива - органолептично. Органолептична оцінка, яку проводять шляхом дегустації, - це оцінка реакції органів відчуття на властивості харчових продуктів, що може бути визначена за допомогою якісних і кількісних методів. Сьогодні широко розповсюджений метод бальної оцінки згідно з умовно прийнятими багатобальними системами. Використовували 5-бальну шкалу таким чином: 5 - дуже подобається, 4 - подобається помірно, 3 - ні подобається, ні не подобається, 2 - не подобається помірно, 1 - насправді не подобається.

Кількість морозива для оцінки якості одного зразка становить 15 г.

Визначення масової частки сухої речовини та вологи. Масову частку сухої речовини в морозиві визначають арбітражним методом шляхом висушування проби при температурі 102-105 ${ }^{\circ} \mathrm{C}$ та експресметодом при висушуванні проби при температурі $180{ }^{\circ} \mathrm{C}$.

Визначення масової частки жиру. Для визначення масової частки жиру в морозиві з умістом жиру згідно 3 рецептурним розрахунком не більше ніж 7,5\% у жиромір для молока відважують 5 г морозива 3 точністю до 0,01 г та обережно, під нахилом жироміра, додають до нього близько $16 \mathrm{~cm}^{3}$ сірчаної кислоти (густина 1500-1550 кг/м ${ }^{3}$ ), щоб рівень рідини був на 4-5 мм нижчим за звуження жироміра біля отвору. Потім вносять $1 \mathrm{~cm}^{3}$ ізоамілового спирту. Жиромір закривають пробкою та струшують, потім перевертають його декілька разів так, щоб рідина у ньому повністю перемішалася.

Жиромір з рідиною ставлять у водяну баню температурою $70{ }^{\circ} \mathrm{C}$ на 15 хв для повного розчинення білків 
та періодично струшують. Потім жиромір ставлять у центрифугу, де проби центрифугують чотири рази по 5 хв. при частоті обертання 1200 об./хв. Після кожного центрифугування жиромір витримують протягом 5 хв. на водяній бані при температурі $65-70{ }^{\circ} \mathrm{C}$. По закінченні центрифугування та витримування жироміра за його шкалою знімають показники. Для визначення масової частки жиру у відсотках показники жироміра множать на коефіцієнт 2,2. Розбіжності між паралельними показниками жироміра при паралельних визначеннях допускаються не більші за одну поділку шкали жироміра. При меншій частоті обертання центрифуги виконують п'яте, контрольне, центрифугування. При визначенні масової частки жиру в молочному морозиві 3 негомогенізованої суміші застосовують одноразове центрифугування. Частота обертання центрифуги повинна бути не меншою за 1000 об./хв.

При визначенні масової частки жиру в морозиві 3 вмістом жиру згідно з рецептурним розрахунком понад 7,5 \% у жиромір для вершків відважують 5 г морозива 3 точністю до 0,01 г та додають близько $16 \mathrm{~cm}^{3}$

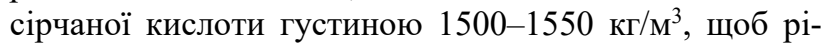
вень рідини був на 6-10 мм нижчим основи звуження жироміра біля отвору. Розбіжності між паралельними визначеннями допускаються до $0,5 \%$. Жироміри центрифугують щонайменше 4 рази. При визначенні вмісту жиру у морозиві з негомогенізованої суміші застосовують одноразове центрифугування 3 частотою обертання центрифуги 1000 об./хв.

Визначення опору морозива до танення. Зразок м'якого або загартованого морозива температурою відповідно -6 або - $18^{\circ} \mathrm{C}$ відбирають спеціальним пробником у вигляді пустотілого циліндра діаметром 35 мм та висотою 50 мм і кладуть у паперовий з полімерним покриттям стаканчик з отворами по краю дна для вільного витікання рідкої суміші.

Опір таненню виражають через тривалість накопичення $10 \mathrm{~cm}^{3}$ суміші (у хвилинах), що утворюється внаслідок розплавлення морозива у термостаті при температурі $25^{\circ} \mathrm{C}$. Цей показник залежить від збитості морозива, дисперсності повітря у продукті та вмісту в ньому вологи.

Визначення густини сумімей. Густину сумішей морозива встановлюють ареометричним методом. Для цього застосовують два типи лактоденсиметрів - 3 термометром та без нього. Ціна поділки шкали у лакто-денсиметрів першого типу - 0,001, другого типу 0,0005.

Вимірювання проводять при температурі суміші $20{ }^{\circ} \mathrm{C}$. Дослідний зразок добре перемішують, обережно наливають по стінках у скляний циліндр місткістю $250 \mathrm{~cm}^{3}$. Чистий та сухий ареометр обережно занурюють у суміш до поділки шкали 1, 100 та залишають вільно плавати до встановлення постійного значення по шкалі. Для унеможливлення похибок вимірювання не допускається, щоб ареометр торкався стінок циліндра. Значення густини відраховують по верхньому краю меніска рідини.

\section{Результати та їх обговорення}

Вплив додавання фініків на колір морозива залежав від їх концентрації, оскільки часткова заміна цукру фініковим сиропом не мала суттєвого впливу на колір, тимчасом як повна заміна фініковим сиропом значно зменшила бал за колір, що може бути пов'язано з коричневим кольором фінікового сиропу. Якщо для часткової заміни бал за колір становив 4,6, то для морозива 3 повною заміною він станови 4,1. Подібні результати спостерігалися при додаванні фінікової пасти.

Всі зразки морозива мали подібне відчуття аромату і смаку - зі смаком фініків. Додавання фінікового сиропу поліпшило смак морозива. Показники смакових відчуттів суттєво зростали зі збільшенням концентрації фінікового сиропу, тобто зразки із повною заміною отримали 4,9 бала проти 4,2 із частковою. Але додавання фінікової пасти не вплинуло на бали смаку і вони становили 4,4. Учасники дегустації віддали перевагу смаку і аромату зразка морозива, виготовленого за рецептурою № 3 .

Отже, всі дослідні зразки отримали позитивну оцінку дегустаційної комісії, що свідчить про можливість заміни сахарози на продукти переробки фініків, а саме фінікову пасту та фініковий сироп і можливість його виробництва за рецептурами, наведеними у табл. 2.

\section{Таблиця 2}

Рецептури морозива

\begin{tabular}{lcccc}
\hline \multicolumn{1}{c}{ Інгредієнти } & \multicolumn{3}{c}{ Рецептура } \\
\cline { 2 - 5 } \multicolumn{1}{c}{ Молоко незбиране } & 1 & 2 & 3 & 4 \\
Рослинна олія & 700 & 700 & 700 & 700 \\
Цукор-пісок & 80 & 80 & 80 & 80 \\
Сироп фініковий & 180 & 90 & - & 90 \\
Паста фінікова & & 90 & 180 & 90 \\
Сухе знежирене молоко & 20 & 90 & 20 & 20 \\
Суха сироватка & 14 & 20 & 14 & 14 \\
Ванілін & 1 & 14 & 1 & 5 \\
Емульгатор/стабілізатор Денайс 855 & 5 & 5 & 5 & 5 \\
\hline
\end{tabular}

Одним із важливих фізико-хімічних показників морозива, що вказує на його свіжість та доброякіс- ність, є кислотність. Також необхідна відповідна в'язкість та густина для забезпечення гарної текстури 
та стійкості до танення. Важливим при формуванні споживчих властивостей $\epsilon$ вміст жиру і сухих речовин у готовому продукті, а також розмір жирових кульок і повітряних бульбашок.
Тому на цьому етапі досліджень визначали основні показники, що забезпечують якість морозива.

Результати дослідження вмісту жиру і сухих речовин наведено у табл. 3 .

Таблиця 3

Хімічний склад морозива

\begin{tabular}{ccc}
\hline Рецептура & Суха речовина (\%) & Жир (\%) \\
\hline 1 & $38,74 \pm 4,22$ & $10,53 \pm 1,76$ \\
2 & $36,52 \pm 5,03$ & $10,84 \pm 2,11$ \\
3 & $37,66 \pm 6,16$ & $10,58 \pm 1,36$ \\
4 & $37,91 \pm 3,95$ & $10,29 \pm 1,85$ \\
\hline
\end{tabular}

Показник жиру забезпечує рослинна олія та молоко незбиране, що входять до рецептури, їх вміст в середньому однаковий і перебуває в межах $10 \%$.

У табл. 4. наведені результати досліджень основних фізико-хімічних показників.

3 табл. 3. видно, що часткова заміна цукру фініковим сиропом або фініковою пастою не мала значного впливу на $\mathrm{pH}$ та кислотність, а повна заміна цукрупіску на фініковий сироп значно знизила $\mathrm{pH}$ та підвищила кислотність, що може бути пов'язано 3 вмістом кислот у ньому.

\section{Таблиця 4}

Основні фізико-хімічні показники морозива
Згідно з результатами, суттєвої різниці у перевищенні густини морозива не було. Вона перебувала в

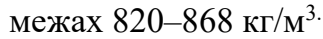

В'язкість - одна 3 найважливіших властивостей морозива, необхідна для гарної текстури та стійкості до танення. Заміна сахарози на продукти переробки фініків (пасту або сироп) збільшила в'язкість морозива. Найнижче значення в'язкості спостерігалось у контрольній пробі, тимчасом як при повній заміні цукру фініковим сиропом було отримано найвище значення в'язкості.

\begin{tabular}{|c|c|c|c|}
\hline Рецептура & $\mathrm{pH}$ & Густина, кг/м ${ }^{3}$ & В'язкість, ср \\
\hline 1 & $6,48 \pm 0,08$ & $868 \pm 32$ & $926,00 \pm 11,00$ \\
\hline 2 & $6,39 \pm 0,21$ & $820 \pm 43$ & $932,67 \pm 13,01$ \\
\hline 3 & $5,90 \pm 0,01$ & $838 \pm 69$ & $2164,33 \pm 15,04$ \\
\hline 4 & $6,32 \pm 0,02$ & $835 \pm 85$ & $1616,00 \pm 16,10$ \\
\hline
\end{tabular}

Враховуючи, що однією з основних характеристик морозива $\epsilon$ опір таненню, проведені дослідження щодо встановлення залежності швидкості танення різних видів рецептурних композицій морозива. Швидкість танення морозива залежить від будови i величини кристалів. Останнє зумовлене рецептурним складом та технологічним процесом виробництва. На швидкість танення морозива впливає також температура навколишнього середовища. Чим меншою $є$ швидкість танення, тим кращою - структура, консистенція і загалом вища споживча цінність продукту. Дослідженнями встановлено, що швидкість танення для контролю та дослідних зразків була в однакових межах і становила 100-110 хв.

Отже, підсумовуючи результати досліджень, можна сказати, що морозиво, виготовлене за новими рецептурами, мало кращі фізико-хімічні показники, ніж контрольний зразок.

\section{Висновки}

1. Розроблено рецептури морозива з частковою та повною заміною сахарози на продукти переробки фініків.

2. Досліджено органолептичні показники морозива. Встановлено, що всі зразки морозива мали подібне відчуття аромату і смаку - зі смаком фініків. Дода- вання фінікового сиропу поліпшило смак морозива. Показники смакових відчуттів суттєво зростали зі збільшенням концентрації фінікового сиропу.

3. Встановлено, що часткова заміна цукру фініковим сиропом або фініковою пастою не мала значного впливу на $\mathrm{pH}$ та кислотність, а повна заміна цукрупіску на фініковий сироп значно знизила $\mathrm{pH}$ та підвищила кислотність, що може бути пов'язано з вмістом кислот у ньому.

4. Досліджено, що заміна сахарози на продукти переробки фініків (пасту або сироп) збільшила в'язкість морозива. Найнижче значення в'язкості спостерігалось у контрольній пробі, тимчасом як при повній заміні цукру фініковим сиропом було отримано найвище значення в'язкості.

\section{References}

Ahmed, I. A., Ahmed, A. W. K., \& Robinson, R. K. (1995). Chemical composition of date varieties as influenced by the stage of ripening. Food chemistry, 54(3), 305-309. doi: 10.1016/0308-8146(95)00051-J.

Al-Farsi, M. A., \& Lee, C. Y. (2008). Nutritional and functional properties of dates: a review. Crit Rev Food Sci Nutr., 48(10), 877-887. doi: 10.1080/10408390701724264. 
Bartkovskyi, I. I., Polishchuk, H. Ye., \& Sharakhmatova, T. Ye. (2010). Tekhnolohiia morozyva. Kyiv: Feniks (in Ukrainian).

Gouhari Ardebili, A., \& Habibi Najafi, M., \& Hadad Khodaparast, M. (2005). Effect of date syrup as a substitute for sugar on the physicochemical and sensory properties of soft ice cream. Iranian food science and technology research journal, 1(2), 23-32. URL: https://www.sid.ir/en/journal/ViewPaper.aspx?id=162 104.

Habib, H. M., \& Ibrahim, W. H. (2009). Nutritional quality evaluation of eighteen date pit varieties. Int $\mathrm{J}$ Food Sci Nutr, 60(1), 99-111. doi: 10.1080/09637480802314639.

Kravchenko, L. V. (2017). Rynok morozyva v Ukraini. Myr produktiv, 3, 8-12 (in Ukrainian).

Milani, E., \& Koocheki, A. (2011). The effects of date syrup and guar gum on physical, rheological and sensory properties of low fat frozen yoghurt dessert. International Journal of Dairy, 64(1), 121-129. doi: 10.1111/j.1471-0307.2010.00631.x.

Mostova, L. M., Nikolenko, O. V., \& Mostova, L. M. (2015). Tekhnolohichni aspekty stvorennia zamorozhenykh desertiv na osnovi naturalnoi syrovyny z vykorystanniam netradytsiinykh stabilizatsiinykh system. Naukovi trudy SWorld, 3(2), 26-29 (in Ukrainian).

Ozdemir, C., Dagdemir, E., \& Ozdemir, S. (2008). The effects of using alternative sweeteners to sucrose on ice cream quality. J. Food Qual., 31(4), 415-428. doi: 10.1111/j.1745-4557.2008.00209.x.

Pavliuk, R. Yu., Poharska, V. V., \& Berestova, A. A. (2013). Innovatsiini tekhnolohii vitaminnoho plodovoyahidnoho morozyva z vykorystanniam zamorozhenykh dribnodyspersnykh dobavok $\mathrm{Z}$ roslynnoi syrovyny. Skhid.-Yevrop. zhurn. peredovykh tekhnolohii, 4(10(64), 57-62 (in Ukrainian).

Sharakhmatova, T. Y., \& Tanasova, G. S. (2015). The use of stevia is in production of diabetic ice-cream. Scientific Messenger of LNU of Veterinary Medicine and Biotechnologies. Series: Food Technologies, 17(4), 192-196. URL: https://nvlvet.com.ua/ index.php/food/article/view/3273.

Turchyn, I. M., Slyvka, N. B., Melnyk, O. R., \& Kopach, V. (2013). Vykorystannia netradytsiinykh komponentiv v tekhnolohii morozyva. Ekotrofolohiia. Prohres, problemy, perspektyvy ekolohichno bezpechnoho vyrobnytstva Materialy IV Mizhnarodnoi naukovo-praktychnoi konferentsii, prysviachenoi 10-richchiu kafedry ekotrofolohii BNAU, 92-93 (in Ukrainian).

Vezhlivtseva, S. P., \& Riaba, O. P. (2019). Analiz yakosti morozyva plombir na spozhyvchomu rynku Ukrainy. Mizhnarodnyi naukovyi zhurnal "Internauka", 1(63), 7-10 (in Ukrainian).

Yang1lar, F. (2015). Mineral contents and physical, chemical, sensory properties of ice cream enriched with date fibre. Italian Journal of Food Science, 27(3), doi: 10.14674/1120-1770/ijfs.v283.

Zgurskyi, A., Polischuk, G., Kalinowskay, T., \& Zgurskay, T. (2015). Technological aspects of pectin -containing raw materials in the production of ice cream. Scientific Messenger of LNU of Veterinary Medicine and Biotechnologies. Series: Food Technologies, 17(1), 2228. URL: https://nvlvet.com.ua/index.php/food/ article/view/3279. 